\title{
PENGARUH PANDEMI COVID-19 TERHADAP HASIL RISET EKSAKTA VS SOSIAL: STUDI PADA REPOSITORY UNAIR
}

\author{
Prasetyo Adi Nugroho \\ Perpustakaan Universitas Airlangga \\ prasetyo.adi@staf.unair.ac.id
}

\begin{abstract}
ABSTRAK
Perguruan tinggi di Indonesia diwajibkan untuk meggalakkan riset. Karya ilmiah merupakan salah satu bentuk riset untuk menentukan peringkat suatu universitas. Penelitian ini bertujuan untuk mengobservasi apakh dampak pandemi Covid-19 berpengaruh pada jumlah publikasi karya ilmiah eksak dan ilmu sosial. Studi ini menggunakan metode kuantitatif berbasis survey. Data yang digunakan merupakan data sekunder yang diambil dari website repository UNAIR. Sampel penelitian ini yakni karya ilmiah yang dipublikasikan oleh Fakultas Ekonomi \& Bisnis (FEB) dan Fakultas Sains \& Teknologi (FST) selama tahun 2019 dan 2020. Hasil studi ini menemukan bahwa pandemic berpengaruh pada tingkat publikasi, dimana jumalh publikasi pada mahasiswa FST turun lebih dari separuh. Mahasiswa FEB juga mengalami penurunan dalam publikasi, kecuali pada jurusan magister ilmu ekonomi. Selain itu, jumlah serta skala publikasi pada FEB lebih besar dibandingkan FST. Hal ini dikarenakan ilmu ekonomi mempunyai lingkup yang lebih luas dan fleksibel jika dibandingkan FST untuk diteliti.
\end{abstract}

Kata kunci: karya ilmiah, pandemi, webometrik

\section{PENDAHULUAN}

Peguruan tinggi merupakan tempat dimana masyarakat mengenyam pendidikan sampai tingkat tertinggi. Perguruan tinggi juga merupakan tempat dimana berbagai bentuk penelitian dihasilkan, yang mana digunakan untuk kepentingan para pelaku usaha, korporasi, serta untuk pengambil kebijakan (Sandy and Shen, 2019). Riset merupakan salah satu kewajiban yang harus dilaksanakan oleh perguruan tinggi sesuai dengan Tri Dharma Pendidikan (Barus and Mungkasi, 2019).

Perguruan tinggi dituntut untuk selalu mengembangkan riset mereka, dikarenakan peringkat pendidikan tinggi di Indonesia mengacu pada Webometric dan QS World University. Dua instansi pemeringkat tersebut menjadikan kualitas serta kuantitas riset pada perguruan tinggi sebagai acuan untuk meranking tingkat pendidikan tinggi suatu negara. Sebagai contoh peringkat Indonesia pada halaman Webometric berada pada peringkat 694 didunia, dan peringkat ini dipegang oleh Universitas Indonesia. Sedangkan Malaysia sebagai negara tetangga berada pada urutan 375, yang mana dipegang oleh Universitas Malaya (Jati, 2011). Hal ini membuat Indonesia masih harus bekerja ekstra keras terhadap jumlah riset pada semua perguruan tinggi di nusantara (Irianto, 2006).

Salah satu upaya yang dilakukan oleh Universitas Negeri yakni memberi insentif pada para akademisi yang telah melakukan penelitian, dibuktikan dengan bukti otentik publikasi 
mereka pada jurnal ilmiah. Jurnal ilmiah sendiri terbagi atas lingkup nasional dan internasional. Jurnal nasional di Indonesia dinilai dengan Sinta, dimulai dengan dari Sinta 6 ke Sinta 1 sebagai tingkatan tertinggi (Nulhaqim et al., 2016). Untuk tingkatan jurnal internasional, kemenristek membagi urutan pada indeks DOAJ untuk internasional secara umum, Scopus dan Web of Science (SCI) untuk tingkatan lanjut. Scopus digunakan untuk kepangkatan dosen serta akreditasi perguruan tinggi pada QS World University. Sedangkan untuk Webometric lebih mengacu pada kuantitas tulisan ilmiah yang tersimpan pada repository universitas masing masing (Harzing and Alakangas, 2016).

Webometric agak berbeda dengan QS World Rank University, dimana jumlah tulisan ilmiah seperti karya mahasiswa tahun akhir juga mempengaruhi skor pada webometric (Aguillo, 2018). Tulisan ilmiah seperti skripsi, tesis serta disertasi merupakan buah pemikiran mahasiswa sebagai syarat kelulusan. Tulisan tulisan ilmiah tersebut tentunya mengandung temuan baru atau inovasi yang dapat diterapkan untuk korporasi, kehidupan sosial, dan teknologi (Mafruchati, 2020). Karya ilmiah merupakan koleksi paling banyak pada universitas, terutama dikota besar. Tiap tahun jumlah lulusan universitas di Indonesia jumlahnya terus meningkat, dikarenakan tuntutan kerja (Jati and Dominic, 2017).

Repository karya ilmiah pada universitas kini telah disimpan dalam bentuk digital selain tersedia bentuk hardcopynya. Hal ini untuk menyesuaikan dengan perkembangan zaman, dimana digitalisasi membuat akses informasi bisa dilakukan dimanapun, sehingga perpustakaan pendidikan tinggi juga dituntut untuk beradaptasi. Selain itu, repository dalam bentuk digital bisa menghemat tempat bagi pihak perpustakaan, diaman versi cetak membutuhkan banyak tempat dan pemeliharaan buku yang mahal (Seeman, 2018).

Salah satu universitas negeri yang menunjang teknologi e-repositori untuk skripsi yakni Universitas Airlangga (UNAIR). Bagi para akademisi, yakni mahasiswa dan dosen, skripsi bisa diakses dimanapun dengan mengakses halaman website perpustakaan UNAIR (Artha, 2017). Studi ini bertujuan untuk menganalisis apakah kebijakan Work from home atau WFH mempengaruhi jumlah karya ilmiah eksak dan ilmu sosial.

\section{TINJAUAN PUSTAKA}

\section{Penelitian Menunjang Perekonomian Suatu Bangsa}

Studi oleh Agustia et al mengemukakan bahwa untuk menjadi negara maju, anggara riset harus mencapai minimal $1 \%$ dari total belanja negara. Semakin banyak inovasi riset, semakin banyak pula produksi unggul suatu negara yang bisa masuk kepasar global. Riset sendiri merupakan ujung tombak suatu perusahaan beskala nasional, terutama dalam bidang teknologi, dikarenakan arus perubahan yang begitu cepat (Agustia et al., 2020).

Untuk memangkas biaya riset, beberapa perusahaan besar bekerjasama dengan pihak perguruan tinggi. Perusahaan menyelaraskan bidang usaha mereka dengan fakultas yang sesuai, sehingga bisa memberdayakan para mahasiswa, agar kelak mereka siap jika terjun didunia kerja (Naz, 2019). Selain itu, perusahaan bisa merekrut talenta talenta kompeten dari universitas, sehingga bisa mengefisiensi biaya rekrutmen, sehingga lulusan yang kompeten bisa melanjutkan proyek riset mereka pada perusahaan (Barus and Mungkasi, 2019).

Karya ilmiah merupakan riset dasar suatu mahasiswa sebagai tolak ukur bahwa yang bersangkutan telah mampu untuk bersaing dipasar kerja. Riset pada karya ilmiah harus 
mengandung suatu temuan baru, baik dibidang sosial, maupun pada ilmu terapan (Nygaard, 2017). Untuk mencapai temuan tersebut, mahasiswa melakukan penelitian selama satu semester atau lebih dengan arahan dari dosen pembimbing, agar waktu dan biaya yang mereka habiskan untuk riset bisa efisien. Semakin banyak suatu temuan yang berguna bagi perusahaan, terutama dalam bidang teknologi, semakin banyak perusahaan yang menginvestasikan dananya kepada perguruan tinggi tersebut (Barus and Mungkasi, 2019).

\section{METODE PENELITIAN}

Studi ini menggunakan metode kuantitatif. Data yang digunakan merupakan data sekunder yang diambil dari website repository.unair.ac.id sebagai data utama. Sampel studi ini yakni jumlah repository karya ilmiah pada Fakultas Sains \& Teknologi (FST), serta pada Fakultas Ekonomi dan Bisnis (FEB). Sampel diambil pada tahun 2019 dan tahun 2020. Alasan studi ini mengambil sampel pada 2 fakultas tersebut dikarenakan FST merupakan fakultas dengan jumlah repository karya ilmiah terbesar untuk kategori eksak, sedangkan FEB untuk kategori ilmu sosial. Data diambil pada tanggal 22 Desember 2020 (ASTUTIK et al., 2018).

Data tentang jumlah karya ilmiah kemudian dibandingkan antara tahun 2019 dan tahun 2020. Data tiap jurusan pada FST dan FEB kemudian diukur skalanya dengan rumus jumlah karya ilmiah jurusan pertahun/jumlah karya ilmiah satu fakultas pertahun. Data disajikan dalam bentuk tabel untuk melihat hasil perbandingan tersebut (Wardhana, 2020).

\section{HASIL DAN PEMBAHASAN}

Tabel 1 Jumlah repository Fakultas Sains \& Teknologi UNAIR

\begin{tabular}{|l|l|l|l|}
\hline \multirow{2}{*}{ Minat program studi } & \multicolumn{2}{|c|}{ Jumlah karya ilmiah } & \multirow{2}{*}{ Skala persentase } \\
\cline { 2 - 3 } & \multicolumn{2}{|c|}{2019} & \multicolumn{2}{c|}{2020} & \\
\hline Fisika & 82 & 11 & $12.93 \%$ \\
\hline Ilmu \& teknologi lingkungan & 63 & - & $4.5 \%$ \\
\hline Kimia & 110 & 10 & $18.84 \%$ \\
\hline Sistem informasi & 38 & 8 & $5.3 \%$ \\
\hline Biologi & 118 & 15 & $19.03 \%$ \\
\hline Matematika & 115 & 19 & $19.53 \%$ \\
\hline Otomatisasi sistem instrumentasi (D3) & - & - & $0.29 \%$ \\
\hline Program studi biologi (S2) & 27 & - & $2.4 \%$ \\
\hline Program studi kimia (S2) & 15 & 5 & $1.5 \%$ \\
\hline Program studi matematika dan IPA (S3) & 20 & 1 & $1.27 \%$ \\
\hline Sistem informasi (D3) & - & - & $0.076 \%$ \\
\hline Statistika & 46 & 7 & $2.95 \%$ \\
\hline Tekno biomedik & 48 & 7 & $3.9 \%$ \\
\hline
\end{tabular}

Tabel diatas menunjukkan bahwa terjadi penurunan yang signifikan pada jumlah koleksi pada tahun 2020. Pendemi corona tidak hanya mengakibatkan penurunan daya tahan tubuh masyarakat akibat terjangan virus, namun juga keterbatasan sumber daya, dalam hal ini fasilitas yang disuguhkan oleh pihak universitas (Bono et al., 2020). Jika dibandingkan tahun sebelumnya, tahun 2020 menyebabkan aktivitas universitas banyak yang terhenti, terutama pada sistem pembelajaran tatap muka. Hal ini menyebabkan pihak universitas menutup seluruh 
akses fasilitas diaera universitas dan mengganti kegiatan belajar mengajar dengan metode daring dan online (Geldsetzer, 2020).

Aristovnik et al dalam studi mereka mengemukakan bahwa akibat dari terbatasnya saran dan prasarana dari universitas yang biasanya digunakan oleh mahasiswa seperti internet gratis, fasilitas buku di perpustakaan, serta akses fasilitas komputer milik universitas menyebabkan produktivitas mahasiswa menurun (Aristovnik et al., 2020). Selain itu, aktivitas fisik diruang publik yang terus dibatasi oleh pemerintah daerah serta pusat menyebabkan banyak tekanan terhadap para akademisi, khususnya mahasiswa.

Banyak kampus mengeluarkan izin cuti sementara bagi para mahasiswa yang terdampak ekonominya disaat pandemi corona. Para mahasiswa menunda studi mereka atau menunda kelulusan mereka, sehingga berdampak pada angka jumlah karya ilmiah yang dihasilkan pada universitas (Megatsari et al., 2020). Hal ini bisa dilihat pada table 1 dimana 3 minat prodi seperti system informasi, biologi, dan matematika mengalami penurunan drastis jumlah karya ilmiah yang dihasilkan. Pada tahun 2019, karya ilmiah yang dihasilkan oleh ketiga prodi diatas mencapai ratusan, namun pada tahun 2020 turun sampai hanya mencapai puluhan, itupun kurang dari 20.

Tabel diatas juga memperlihatkan bahwa prodi matematika, kimia, biologi, dan fisika mempunyai skala karya ilmiah terbesar dibandingkan prodi yang lain. Prodi prodi tersebut merupakan ilmu eksak dasar yang bisa diaplikasikan pada bidang kerja manapun, sehingga bisa melingkupi banyak area penelitian, termasuk topik penelitian yang berhubungan dengan program studi lain. Berbeda dengan program studi lain yang benar benar spesifik bidang kerjanya, sehingga lingkup penelitian yang bisa diteliti lebih terbatas (Fadhly et al., 2018).

Tabel 2 Jumlah repository Fakultas Ekonomi \& Bisnis UNAIR

\begin{tabular}{|c|c|c|c|}
\hline \multirow[t]{2}{*}{ Minat program studi } & \multicolumn{2}{|c|}{ Jumlah karya ilmiah } & \multirow[t]{2}{*}{ Skala persentase } \\
\hline & 2019 & 2020 & \\
\hline Akuntansi & 405 & 218 & $35.14 \%$ \\
\hline Ilmu akuntansi (S3) & 13 & - & $0.21 \%$ \\
\hline Ilmu ekonomi (S3) & 10 & 1 & $0.24 \%$ \\
\hline Ilmu manajemen (S3) & 6 & 4 & $0.08 \%$ \\
\hline Ekonomi pembangunan & 194 & 84 & $12.64 \%$ \\
\hline Ekonomi syariah & 259 & 127 & $16.38 \%$ \\
\hline Ilmu ekonomi (S2) & 9 & 22 & $0.22 \%$ \\
\hline Ilmu akuntansi (S2) & 79 & 38 & 2.1 \\
\hline Ilmu manajemen (S2) & 118 & 41 & $3.6 \%$ \\
\hline Sains manajemen (S2) & 28 & 35 & $1.79 \%$ \\
\hline Manajemen & 416 & 137 & $30.35 \%$ \\
\hline
\end{tabular}

Tabel 2 menunjukkan bahwa ada penurunan drastis pula pada FEB. Pengaruh PSBB, pelarangan pembelajaran tatap muka di universitas, serta keterbatasan fasilitas penunjang yang dimiliki oleh mahasiswa kerap menjadi penyebab utama penurunan ini. Penurunan jumlah bahkan hamper mencapai separuh dari jumlah karya ilmiah pada tahun 2019. Tabel 2 juga menunjukkan program studi akuntansi memiliki skala persentase karya ilmiah terbesar 
dibandingkan prodi lain, diikuti oleh manajemen. Namun yang menarik adalah hanya prodi magister ilmu ekonomi justru mengalami kenaikan.

Ilmu ekonomi merupakan fondasi bagi para lulusan untuk berkiprah diperusahaan besar ataupun UKM. pengetahuan tentang ekonomi sangat penting bagi para fresh graduate untuk berkarier, terutama pada perusahaan berskala nasional dan multi nasional (Isnaini and Lestari, 2016). Terlebih lagi, untuk para lulusan yang ingin membangun UKM, pengetahuan ekonomi, khususnya kemampuan marketing menjadi modal utama agar usaha yang dimiliki bisa terus bertahan (Edy and Castleberry, 2019).

Tabel 2 juga memperlihatkan bahwa jumlah karya ilmiah, serta skala persentase karya ilmiah FEB melampaui FST. Dalam hal jumlah publikasi ditahun 2020 pun, FEB masih mengungguli FST. Hal ini dikarenakan ruang lingkup ilmu ekonomi dan bisnis yang begitu luas serta lebih bisa dikembangkan untuk menghadapi himpitan ekonomi dikala pandemi (Dewi, 2018). Persoalan ekonomi memang seharusnya diselesaikan dengan pengetahuan perekonomian pula, agar lebih efisien dalam menghabiskan waktu dan sumber daya yang ada (Zenko, 2020). Selain itu, jurusan seperti akuntansi dan manajemen lebih mempunyai lingkup yang luas, terlebih lagi disaat pandemi dimana hamper semua perusauaah besar, menengah, dan kecil terdampak dan mengalami kesulitan dalam mempertahankan usahanya. Hal ini bisa dijadikan bahan penelitian dengan lingkup yang beragam oleh mahasiswa ilmu ekonomi. (Huang et al., 2020)

\section{PENUTUP \\ KESIMPULAN}

Berdasarkan hasil diatas, dapat ditarik kesimpulan bahwa pandemic ditahun 2020 mempunyai pengaruh pada jumlah karya ilmiah yang dipublikasikan oleh mahasiswa. Hal ini dikarenakan keterbatasan fasilitas milik universitas, pembatasan kegiatan fisik diruang publik, serta serangan virus yang menurunkan kekebalan tubuh. Disisi lain, ilmu ekonomi lebih mempunyai kemudahan untuk diteliti, dibandingkan dengan eksak. Jumlah dan skala karya ilmiah mahasiswa FEB lebih besar dibandingkan FST. Lingkup penelitian yang terbatas jika dibandingkan ilmu ekonomi merupakan salah satu penyebabnya.

\section{SARAN}

Pada penelitian selanjutnya diharapkan peneliti mengambil lingkup penelitian tidak hanya eksakta dan ilmu sosial namun lebih luas dari itu sehingga hasil penelitian dengan metode kualitatif mampu menghasilkan data yang lebih komprehensif. 


\section{DAFTAR PUSTAKA}

Aguillo, I.F., 2018. Altmetrics of the Open Access Institutional Repositories: A Webometrics Approach, in: 23rd International Conference on Science and Technology Indicators (STI 2018), September 12-14, 2018, Leiden, The Netherlands. Centre for Science and Technology Studies (CWTS).

Agustia, D., Permatasari, Y., Fauzi, H., Sari, M.N.A., 2020. Research And Development Intensity, Firm Performance, And Green Product Innovation. J. Secur. Sustain. Issues 9.

Aristovnik, A., Keržič, D., Ravšelj, D., Tomaževič, N., Umek, L., 2020. Impacts of the COVID-19 pandemic on life of higher education students: A global perspective. Sustainability 12,8438 .

Artha, A.F., 2017. Academic Article World Lists: A Corpus-Based Study On The Articles Published By Elsevier.

Astutik, D., Harymawan, I., Nasih, M., 2018. The Effectiveness of Social Media and Press Release Transparency to Detect Indications of Financial Fraud. Editor. Board 1507.

Barus, G., Mungkasi, S., 2019. On the Publication of Research Papers in the Area of Character Education. Int. J. Mech. Eng. Technol. 10.

Bono, G., Reil, K., Hescox, J., 2020. Stress and wellbeing in urban college students in the US during the COVID-19 pandemic: Can grit and gratitude help? Int. J. Wellbeing 10.

Dewi, A.U., 2018. Towards knowledge economy: A comparative study of Indonesian and South Korean internationalization of higher education. KnE Soc. Sci. 63-83.

Edy, J.A., Castleberry, G.L., 2019. The political economy of global memory: Shared memory of global conflict in Captain America: The First Avenger. Mem. Stud. 1750698019843957.

Fadhly, F.Z., Emzir, E., Lustyantie, N., 2018. Exploring Cognitive Process Of Research Topic Selection In Academic Writing. English Rev. J. English Educ. 7, 157-166.

Geldsetzer, P., 2020. Knowledge and perceptions of COVID-19 among the general public in the United States and the United Kingdom: A cross-sectional online survey. Ann. Intern. Med.

Harzing, A.-W., Alakangas, S., 2016. Google Scholar, Scopus and the Web of Science: a longitudinal and cross-disciplinary comparison. Scientometrics 106, 787-804.

Huang, Y., Lin, C., Wang, P., Xu, Z., 2020. Saving China from the Coronavirus and Economic Meltdown: Experiences and Lessons. Available SSRN 3570696.

Irianto, G., 2006. Transforming State University into Autonomous State University in Indonesia: Opportunities and Challenges (The Case of Brawijaya University). Assoc. South East Asian Institutions High. Educ. 92.

Isnaini, N.S.N., Lestari, R., 2016. Kecemasan pada Pengangguran Terdidik Lulusan Universitas. Indig. J. Ilm. Psikol. 13.

Jati, H., 2011. Web impact factor: a webometric approach for Indonesian universities, in: International Conference on Informatics for Development. pp. 74-77.

Jati, H., Dominic, D.D., 2017. A New Approach of Indonesian University Webometrics Ranking Using Entropy and PROMETHEE II. Procedia Comput. Sci. 124, 444-451. 
Mafruchati, M., 2020. The Use of Dates against COVID-19, based on Effectiveness or Religion's Believe? Trends and Relevance Analysis in Big Data. Vaccine 1, 0.

Megatsari, H., Laksono, A.D., Ibad, M., Herwanto, Y.T., Sarweni, K.P., Geno, R.A.P., Nugraheni, E., 2020. The community psychosocial burden during the COVID-19 pandemic in Indonesia. Heliyon 6, e05136.

Naz, S., 2019. Impact of Globalization on Higher Education in Pakistan: Challenges and Opportunities. Int. J. Innov. Teach. Learn. 2.

Nulhaqim, S.A., Heryadi, D.H., Pancasilawan, R., Ferdryansyah, M., 2016. Peranan Perguruan Tinggi dalam Meningkatkan Kualitas Pendidikan di Indonesia untuk Menghadapi ASEAN Community 2015 Studi Kasus: Universitas Indonesia, Universitas Padjadjaran, Institut Teknologi Bandung. Share Soc. Work J. 6, 197.

Nygaard, L.P., 2017. Publishing and perishing: an academic literacies framework for investigating research productivity. Stud. High. Educ. 42, 519-532.

Sandy, W., Shen, H., 2019. Publish to earn incentives: how do Indonesian professors respond to the new policy? High. Educ. 77, 247-263.

Seeman, C., 2018. When is a Library No Longer a Library? The Future of All-Digital Academic Libraries. Passing from 'traditional' to modern.

Wardhana, A.K., 2020. Information search trends about sharia: a comparation study between business-industry genre with book-literature genre. J. Halal Prod. Res. 3, 35-42.

Zenko, M., 2020. The Coronavirus Is the Worst Intelligence Failure in US History. Foreign Policy 25. 